\title{
Há Abstração de Si na Origem de Toda a Abstração na Filosofia de Espinosa?
}

[Is There an Auto-Abstraction within All Abstraction in Spinoza's Philosophy?]

\section{Rafael Arcanjo Teixeira周 Cristiano Novaes de Rezende***}

Resumo: Inserido no contexto histórico de críticas à abstração, Espinosa retoma o tom de sua época e faz severas advertências contra as abstrações. Entretanto, a crítica espinosana difere de outras da mesma época. Acreditamos que a distinção de Espinosa ocorre porque para ele a abstração não é apenas uma metodologia epistêmica (o ato de separar e fragmentar os objetos do conhecimento), nem é o estabelecimento arbitrário de princípios para conhecimento por meio da interferência da vontade no intelecto. Nossa hipótese é que para Espinosa a abstração ocorre quando a força mental produtiva não se encontra enquanto tal; em outros termos: quando a mente não tem consciência do seu próprio produzir - é precisamente isso o que chamamos de abstração de si. Nosso artigo visa abordar essa hipótese e apontar como o conceito de abstração de si pode auxiliar na interpretação de algumas teses espinosanas. Ao final deste artigo analisaremos como o conceito de abstração de si oferece uma chave interpretativa para a hipótese-retórica que abre o Tratado Teológico-Político.

Palavras-chave: abstração, Espinosa.

Abstract: Spinoza's criticism of abstraction retakes the common tone of his own time warning against etc. Nevertheless, the spinozistic critique differentiates considerably from his contemporaries, whereas he also criticize some of the philosophers that stand against the concept of abstractions. We believe that Spinoza's distinctiveness occurs because he consider abstraction not only as some epistemic methodology (the act of select, divide and disintegrate the objects of knowledge), neither the arbitrary foundation of principles for knowledge through the interference of Will in the Intellect. But rather as the productive mental force when it is not within itself, therefore, when the productive mental force isn't what it should be as it naturally is. In other words: when the mind has not the counscioness of its own work it's precisely this what we call auto-abstraction. Moreover, our article aims to approach this hypothesis and elaborate how exactly the concept of selfabstraction can help us understand some of the spinozian thesis, so that we may focus on the rhetorical hypothesis that opens the Theological-Political Treatise.

Keywords: abstraction, Espinosa.

\footnotetext{
*Bacharel em Filosofia pela Universidade Federal de Goiás (UFG). Atualmente realiza pós-graduação latu sensu em Docência do Ensino Superior (pela FARA - Faculdade Araguaia). Também é membro do Programa de Direitos Humanos da PUC-Goiás (extensão). E-mail: rarcanjo32@gmail.com. ORCID: https://orcid.org/0000-0001-5359-885X.

**Professor da Faculdade de Filosofia da UFG. Doutor em filosofia pela USP. E-mail: cnrz1972@gmail.com. ORCID:
} 
Em uma conceituação geral, abstrair consiste em considerar a parte predicativa de uma sentença separada de sua parte nominal. Em outras palavras, trata-se de tomar os predicados de maneira isolada desconsiderando que por definição um predicado vincula-se a outra coisa sobre a qual ele predica algo. Podemos também recorrer à etimologia para compreendermos o que é uma abstração. A palavra abstração é a tradução portuguesa para o termo latino abstractio que é originário de abstrahere e este, por sua vez, é fruto da junção do prefixo $a b$ (que tem o sentido de afastamento e distância - como no caso de abstinência) com trahere (que significa puxar, como no caso de extraho - extrair). Assim, abstrahere, em sua literalidade, significa puxar para longe, separar e extrair algo do todo ao qual pertence. Abstracte é o que foi separado, isolado ou afastado. Ainda no nível da linguagem vale lembrar que os gramáticos dividem os substantivos em abstratos e concretos. José Vicente César comenta que são considerados abstratos aqueles substantivos que não subsistem sozinhos - em geral são qualidades de seres concretos como amor, justiça, beleza etc. Para César, expressões como "a bondade em pessoa" são tentativas de concretizar substantivos que por natureza são abstratos (CÉSAR, J. V. 1958, p. 26). Ao contrário dos substantivos concretos que se referem às coisas cuja a existência é autônoma, os substantivos abstratos andam "encostados" em sujeitos (CÉSAR, J. V. 1958). Domingos de Azevedo, na Gramática Nacional de Lisboa, classifica como abstrato o "substantivo que designa propriedades ideais comuns a muitos indivíduos, como: virtude, honra [...] e os adjetivos e os infinitos dos verbos substantivados pelo artigo, exprimindo qualidades ou sujeito indeterminado como: o belo, o grande, o viver" (1889, p. 43-4 apud, idem, p. 28). César, voltando-se mais para o terreno da filosofia, comenta que na tradição aristotélica o ser enquanto substância (ov̉oí $\alpha$ ) representa aquilo que não depende ou não decorre de outro para ser e, consequentemente, a substância é a região do concreto. Em contrapartida, os acidentes se dividem em três grupos: (I) os que são concretos, (II) os que oscilam conforme o uso e (III) os que sempre são abstratos ${ }^{1}$ (CÉSAR, J. V. 1958). De acordo com César pertencem ao primeiro grupo as categorias (ou predicamentos) que podem existir sem estarem necessariamente vinculadas a um sujeito; a dizer: lugar ( $\pi \circ \tilde{v}, u b i)$, tempo ( $\pi \circ \tau \varepsilon \dot{\varepsilon}$, quando), es-

\footnotetext{
${ }^{1}$ César comenta que no caso da quantidade há uma oscilação entre a gramática e a filosofia: as gramáticas tomam a quantidade como um substantivo concreto, enquanto os filósofos podem tomá-la em sentido transcendental e, por isso, de maneira abstrata. No caso o autor toma a posição gramatical.
} 


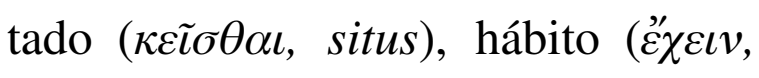
habere). Por sua vez, encontram-se no grupo dos oscilantes a ação ( $\pi O \iota$ -

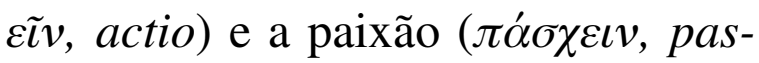
sio). Finalmente, quantidade ( $\pi$ oбóv, quantitas), qualidade ( $\pi \circ$ o $o ́ v$, qualitas) e relação ( $\pi \varrho o ́ s ~ \tau \iota$, relatio) são predicamentos abstratos uma vez que eles estão intimamente vinculados a algo (a um sujeito) $)^{2}$ A partir do que foi dito, podemos observar que o termo abstração geralmente aparece associado: (I) à ideia de impossibilidade de existência concreta e autônoma da coisa referida; (II) à substantivação daquilo que geralmente (ou constantemente) é um adjetivo e (III) ao processo de isolar o predicado de um sujeito.

Feitas essas considerações de âmbito geral, faz-se necessário, para o fim proposto neste artigo, uma breve digressão a respeito do debate sobre as abstrações no século XVII. Nós tomaremos dois exemplos paradigmáticos: Antoine Arnauld e Pierre Nicole com a sua Logique e Francis Bacon com o Novum Organum. Não entraremos nas minúcias dos textos desses autores já que, antes de entrarmos nas análises do texto espinosano, pretendemos fornecer ao leitor apenas um vislumbre amplo da discussão seiscentista acerca da abstração.

Ao voltarmos nosso olhar para o século XVII vemos que o termo abstração possui sentidos diversos. Antoine Arnauld e Pierre Nicole explicam, por exemplo, no capítulo $\mathrm{V}$ da Logique que, graças à parca extensão de nosso espírito, só podemos compreender as coisas compostas de forma perfeita "se as considerarmos por partes e segundo os diversos aspectos que elas podem assumir" (2016 [1683], p. 81) e concluem: "é isso que em geral se chama conhecer por abstração" (idem, ibidem-itálicos nossos). Deste modo, para os jansenistas a abstração é uma espécie de metodologia que possibilita a compreensão das coisas complexas ${ }^{3}$.

Arnauld e Nicole oferecem três exemplos sobre essa maneira de "conhecer por abstração": (I) a anatomia, (II) a geometria e (III) o cogito - que para nós é o mais abstrato de todos. Para eles o primeiro caso não é uma abstração propriamente dita, de fato o corpo é formado por partes distintas uma das outras e seria impossível adquirir conhecimento do corpo caso não tomássemos as suas partes separadas umas das outras. O exemplo anatômico é correspondente, para os jansenistas, ao caso da aritmética: "toda a aritmética se funda também nisto" (idem, p. 82). Levando-se em conta que não precisamos de nenhuma capacidade espe-

\footnotetext{
${ }^{2}$ Não nos interessa aqui questionar a validade do comentário de César a respeito da lógica aristotélica, antes, nós o citamos porque ele apresenta de maneira sucinta o sentido geral que o termo "abstração" assume.

${ }^{3}$ Vale ressaltar que a definição que Arnauld e Nicole oferecem para o "conhecer por abstração" mantém-se fiel à origem etimológica do termo abstração que traz em si a ideia de separação e extração.
} 
cial ou de grande esforço para contar os números pequenos, "toda a arte consiste em contar por partes aquilo que não poderíamos contar pelo todo" (idem, ibidem). Destarte, ao lidarmos com números grandes é preciso fazer na aritmética o que o anatomista faz com o corpo: decompor em partes e considerá-las uma a uma em separado. Isso torna evidente que no caso da metáfora anatômica Arnauld e Nicole tomam a abstração como metodologia que procede em ordem analítica. O segundo exemplo dado por Arnauld e Nicole é o dos geômetras que, segundo eles, para melhor conhecer os corpos extensos partem primeiramente de apenas uma das três dimensões, o comprimento (chamandoos de linhas); depois os consideram segundo duas dimensões, o comprimento e a largura (chamando-os de superfícies); e, por fim, consideram os corpos extensos em todas as três dimensões, comprimento, largura e profundidade (chamando-os de sólidos ou corpos) (idem, ibidem). Embora à primeira vista o método exposto neste segundo exemplo pareça possuir alguma coisa da ordem sintética - já que se procede do mais simples ao mais complexo ordem de composição -, os jansenistas explicam que os geômetras "não supõem de maneira nenhuma que haja linhas sem larguras ou superfícies sem profundidades, tão somente acreditam que se pode considerar o comprimento sem prestar atenção à largura [...]" (idem, p. 83). O que ocorre no caso dos geômetras é, também, uma separação do complexo em partes, ou melhor, é, pelo menos no momento inicial, uma desconsideração dos fatores de complexidade - as intersecções entre as dimensões. Para Arnauld e Nicole é essa metodologia que torna o espírito "capaz de melhor conhecer" (idem, ibidem) $)^{4}$.

O terceiro exemplo oferecido por Arnauld e Nicole é mais peculiar e, em nossa leitura, é o que mais propriamente pode ser qualificado como abstração5. Trata-se do cogito universalizado para todos os seres pensantes. Arnauld e Nicole explicam que se eu reflito sobre o fato de estar a pensar e, neste caso, sou eu o que pensa, posso, a partir de um processo de abstração, "aplicar-me na consideração de uma coisa que pensa sem prestar atenção ao facto de ser eu, [...] eu e aquele que pensa sejam a mesma coisa" (idem, p. 84). Neste caso há

\footnotetext{
${ }^{4}$ Aqui, assim como no caso da anatomia e da aritmética, a abstração é tomada como um método de aprendizagem. No primeiro caso, o método de decompor em partes menores é adequado graças à incapacidade da mente e à natureza dos objetos que são compostos por partes. No segundo caso, o método facilita o conhecimento de coisas que em sua concretude não existem separadas umas das outras. Vale ressaltar que a maneira em que Arnauld e Nicole tomam a geometria aqui não permite que ela seja concebida como ciência puramente conceitual. Ao afirmar que no real não há linhas sem largura Arnauld e Nicole vinculam geometria e extensão, aliás, o próprio conceito de linha (sem largura) é tomado como uma abstração que tem papel meramente metodológico e didático.

5 Isto é, segundo uma perspectiva espinosana.
} 
uma cisão imposta entre o pensante e o pensamento, cisão que se manifesta na passagem da ideia do "eu penso" para a consideração "de uma coisa que pensa". Essa cisão permite a generalização do cogito, como explica Arnauld e Nicole: "assim a ideia que eu conceberia de uma pessoa que pensa poderia representar-me, não somente a mim, mas a todas as outras pessoas que pensam" (idem, ibidem). Neste caso a abstração opera por cisão e generalização. Isso é possível porque, nas palavras dos jansenistas, "perante uma mesma coisa que tem diferentes atributos, pensamos num deles sem pensar nos outros, ainda que haja entre eles uma tão-só distinção de razão" (idem, p. 83). A referência à distinção "tão-só de razão" é importante, pois no cogito não é possível separar realmente o pensante e o pensamento (da mesma maneira que não é possível separar um passeante do passear). No entanto, é possível transportar o cogito para uma instância abstrata e generalizante: a coisa que pensa. Esse transporte só pode ocorrer graças à cisão "tão-só de razão" entre o eu pensante e o pen- samento, isso é, só pode ocorrer na medida em que é desfeita a autorreferência presente no "eu penso" por meio da extração do "eu" — o que Arnauld e Nicole chamam de desconsiderar alguns atributos de uma coisa 6 . Assim, o que a Lógica de Port-Royal chama de abstração é uma metodologia que opera por meio da decomposição do concreto em conceitos cada vez mais elementares e gerais; processo que possibilita a ida do singular concreto ao universal. Por vezes os jansenistas parecem misturar o método analítico com o processo de abstração. Ainda assim, nos três exemplos dados por Arnauld e Nicole para o "conhecer por partes" há menções a uma suposta ampliação do conhecimento: no primeiro exemplo é dito que não é possível possuir um conhecimento da anatomia ou realizar cálculos aritméticos se não decompor o corpo ou os números em partes; no segundo exemplo essa separação em partes constitui a maneira pela qual os geômetras conhecem os sólidos; e, por fim, no terceiro exemplo a abstração permite a ascese ao mais geral e mais elementar (além de permitir a

\footnotetext{
${ }^{6}$ Arnauld e Nicole oferecem um exemplo complementar deste terceiro modo de conceber as coisas abstratamente: a passagem da imagem de um triângulo à ideia de extensão pura. Este exemplo estrutura-se da seguinte maneira: (I) supondo que eu tenha desenhado sobre o papel um triângulo equilátero, na medida em que eu considerar apenas este triângulo poderei ter apenas a ideia de um triângulo. (II) No entanto, se eu afastar o meu espírito da consideração de todos os acidentes que o determinam - fatores de singularização - e se eu aplicar-me a pensar que se trata de uma figura limitada por três linhas iguais eu ficarei apenas com a ideia de triângulo equilátero. (III) Se eu for mais longe e ignorar a igualdade entre as linhas, considerando que se trata apenas de uma figura determinada por três linhas retas, poderei formar uma ideia que representa todos os triângulos - um conceito universal de triângulo. (IV) Se, além disso, eu desconsiderar as três linhas e focar apenas no fato de que se trata de uma superfície plana limitada por linhas poderei chegar à ideia de figura retilínea, e "assim posso subir grau a grau até a pura extensão" (ARNAULD, A.; NICOLE, P. 2016 [1683], p.84). Curiosamente este exemplo inverte a ordem do segundo modo de conhecer por abstração, pois aqui o ponto de partida é o complexo (um singular concreto: o desenho de triângulo) enquanto que lá parte-se do ponto para a reta e desta para o plano até chegar à ao corpo (o complexo).
} 
generalização de conceitos, como no caso do cogito).

Em sentido oposto à lógica de Arnauld e Nicole, Bacon faz severas críticas às abstrações. No aforismo XXII do Novum Organum, o barão de Verulam fala que enquanto a verdadeira via para o conhecimento se detém de forma ordenada nos dados da experiência sensível e se eleva gradualmente às coisas que realmente são as "mais comuns na natureza", a outra via "desde o início estabelece certas generalizações abstratas e inúteis" (BACON, 1999 p. 36). Para Bacon tanto a via do erro quanto a da verdade partem dos dados sensíveis e da experiência, ou seja, as vias não se distinguem quanto à origem de seus conteúdos. Partindo ambas de um mesmo ponto elas só podem se diferenciar quanto ao método. No aforismo IX, Bacon fala que todos os males na ciência se originam quando "admiramos e exaltamos de modo falso os poderes da mente" (idem, p. 34) e, também, no aforismo $X$ ele ressalta que a "natureza supera em muito, em complexidade, os sentidos e o intelecto" (idem, ibidem). Além disso, para Bacon "a mente anseia por ascender aos princípios mais gerais para aí se deter" (idem, p. 36). Assim, a abstração ocorre quando a mente voluptuosa não se detém nos dados primários passando a experiência na carreira a fim de estabelecer os princípios pelos quais passará a julgar os novos dados sensíveis - princípios estes que terão bases precárias e, por isso, aproximarão mais da ficção que do conhecimento verdadeiro. No aforismo XLVIII, Bacon afirma que o intelecto humano jamais pode encontrar repouso; agitado, ele sempre procura ir além. "Daí ser impensável, inconcebível, que haja um limite extremo e último do mundo. Antes, sempre ocorre como necessária a existência de algo além" (idem, p. 43). Para Bacon, o intelecto humano, em um determinado domínio de suas atividades (aquele da via que conduz ao erro) se vê atormentado por questões às quais não pode evitar e, no entanto, não pode responder. Como ele fala no aforismo XLVI: "o intelecto humano, quando assente em uma convicção, tudo arrasta para seu apoio e acordo" (idem, p. 42). No aforismo XLIX, Bacon afirma que "o intelecto humano não é uma luz pura, pois recebe a influência da vontade e dos afetos, donde poder gerar a ciência que se quer" (idem, p. 43). Deste modo, sendo o intelecto uma luz afetada pela vontade ele tende a produzir a "ciência que se quer" (idem, ibidem), ou seja, pode compor como ciência o que lhe apetecer. A conclusão desses encadeamentos vem no aforismo LI, no qual Bacon fala que "o intelecto humano, por sua própria natureza, tende ao abstrato [...]" e, assim, "é melhor dividir em partes a natureza do que traduzi-la em abstrações" (idem, p. 44). Desta maneira, Bacon toma as 
abstrações num registro diferente do tomado por Arnauld e Nicole. No Novum Organum, a abstração não aparece como o método de divisão em partes, mas como negligência, confusão, arrogância e cupidez que levam ao estabelecimento de princípios gerais incapazes de apreender a concretude e complexidade da natureza. Negligência porque $\mathrm{o}$ intelecto estabelece na carreira os princípios sobre os quais irá fundamentar-se, sem se deter cuidadosamente nos dados empíricos. Confusão porque sem o devido cuidado o intelecto acaba misturando aquilo que lhe é próprio - as abstrações - com aquilo que é da natureza. Arrogância porque tal confusão nasce de um narcisismo epistêmico no qual o homem admira desmedidamente o engenho de seu intelecto. Cupidez porque o intelecto opera sob a influência da vontade e, por isso, faz a ciência "que se quer".

Enquanto para Arnauld e Nicole a abstração está mais vinculada ao sentido etimológico do termo, isto é, ao processo de separação e decomposição, para Bacon ela se aproxima do ficcional por ser o estabelecimento de alguns princípios abstraídos de parcas experiências - de sorte confusas e misturadas com elementos que pertencentes apenas ao espírito humano. $\mathrm{O}$ núcleo dessa divergência se encontra na maneira pela qual cada uma das duas perspectivas toma a relação homem e natureza. Partindo do pressuposto agostiniano de uma ordem hie- rárquica dos seres, os jansenistas Arnauld e Nicole têm cravado em suas mentes as palavras de Agostinho no De Vera Religione: "o que julga é maior do que o julgado" (AGOSTINHO, 1987, p. 88). Sendo assim, o espírito humano possui ontologicamente garantida a capacidade e o direito de julgar e determinar o conhecimento segundo uma lei própria, ou melhor dizendo, segundo uma lei que transcende à própria natureza e que se encontra assegurada na própria iluminação divina. Bacon, por outro lado, parte do pressuposto de que o intelecto humano "por sua própria natureza" é corrompido. Isso fica mais evidente se tomarmos nota do que Bacon fala em The Interpretation of nature e, também, no The advancement of learning. No primeiro, Bacon escreve que o homem, sendo investido por Deus desde a criação "da soberania de todas as coisas [...] não tinha necessidade de poder ou de domínio" (BACON, 1963, p. 217 op. cit. in ZATERKA, 2004, p. 96-7); já no Advancement, Bacon afirma que o verdadeiro fim do conhecimento é a "restituição e restauração do homem à soberania e ao poder que ele tinha no primeiro estágio da criação" (idem, p. 222 op. cit. idem, p. 98). Para Bacon o homem perdeu aquele poder que tivera nos primórdios da criação, quando ele foi capaz de 'chamar as criaturas pelos seus nomes e comandá-las' (idem, ibidem). É a perda desse domínio 
que consiste na própria fraqueza do intelecto. Se no aforismo III do primeiro livro do Novum Organum Bacon afirma que "ciência e poder do homem coincidem" é porque ele está convicto de que o projeto científico é uma restauração de um poderio perdido. Além disso, se no mesmo aforismo Bacon afirma que se deve obedecer a natureza para vencê-la, isso ocorre porque na perspectiva baconiana o intelecto já não possui mais aquela força e capacidade necessária para, a partir de si mesmo, fazer a ciência. Não devemos esquecer as palavras finais do segundo livro do Novum Organum: "Pelo pecado o homem perdeu a inocência e o domínio das criaturas. Ambas as perdas podem ser reparadas, mesmo que em parte, ainda nesta vida; a primeira com a religião e com a fé, a segunda com as artes e com as ciências." (BACON, 1999, p. 218)7. Deste modo, podemos concluir a partir da análise do exemplo de Bacon e dos jansenistas Arnauld e Nicole que o tema da abstração nos seiscentos ultrapassa os limites da mera epstemologia e aparece envolto de questões teológicas. Além disso, tanto Bacon quanto Arnauld e Nicole se encaixam naquilo que podemos chamar de epistemologias da dominação; o primeiro critica as abstrações pois acredita que por meio disso os homens poderão recuperar o domínio sobre a natureza, os segundos tomam a abstração como metodologia pois acreditam que os homens possuem ontologicamente garantida a capacidade de domínio. Entretanto, paradoxalmente nos dois casos citados a abstração aparece vinculada à incapacidade humana: seja entendida como método para a sua superação, seja entendida como desdobramento de nossa fragilidade.

$$
* * *
$$

Espinosa se insere no contexto das críticas modernas às abstrações. Retomando o tom crítico de sua época ele faz severas advertências contra as abstrações. No TIE ${ }^{8}$ ele assevera: "um máximo engano [...] origina-se do seguinte: eles concebem as coisas abstratamente demais" (TIE, §74-5). Alguns parágrafos à frente ele faz a seguinte exortação: "nunca nos será

\footnotetext{
${ }^{7}$ É justamente essa concepção abstrata que Espinosa implode na abertura do TTP. Nós faremos uma análise detalhada sobre isso no tópico deste artigo intitulado "Um exemplo de como opera a crítica espinosana à abstração de si: a abertura do Tratado Teológico-Político".

${ }^{8}$ As obras de Espinosa serão citadas com as seguintes siglas e abreviaturas: E: Ética demonstrada em ordem geométrica. As partes serão indicadas em algarismos romanos. Em algarismos arábicos, acompanhados de abreviaturas, serão indicados: as definições, suas explicações; os axiomas; os enunciados das proposições, suas demonstrações, os seus escólios; os prefácios e o apêndice; exemplo: E, III, P24, schol. TIE: Tratado da Emenda do Intelecto (lat.: Tractatus de Intellectus Emendatione). Os parágrafos serão indicados com § seguido da numeração correspondente (TIE §7). As seguintes abreviaturas serão utilizadas para se referir às obras de Espinosa: TTP: Tratado Teológico-Político. TP: Tratado Político. CM: Cogitata Metafísica. Todas as citações da Ética são referentes à tradução realizada pelo Grupo de Estudos Espinosanos da USP, publicada em 2015 pela Editora Edusp (referenciada na Bibliografia). Todas as citações do Tratado da Emenda do Intelecto são referentes à tradução de Cristiano Novaes Rezende, publicada em 2015 pela Editora da Unicamp (referenciada na Bibliografia). As demais obras de Espinosa (incluindo do TTP e o TP) serão citadas de acordo com as normas vigentes da ABNT para citações.
} 
lícito, enquanto tratarmos da Inquisição das coisas, concluir algo a partir de abstrações" (idem, §93). Assim, Espinosa possui uma posição contrária à de Arnauld e Nicole, já que para o filósofo a abstração jamais pode ser tida como um método para o verdadeiro conhecimento. Entretanto, isso não o aproxima de Bacon. Ao contrário, ao ser questionado por Oldemburg a respeito de quais erros ele imputava a Bacon e a Descartes, Espinosa responde que, embora não esteja acostumado a assinalar os erros cometidos por outros, irá expor os três principais erros de ambos: "primeiro estão muitíssimo distanciados de conhecer a primeira causa e a origem de todas as coisas. [... depois] não conhecem verdadeiramente a natureza da alma humana. [... por fim] jamais aprenderam a causa do erro" (ESPINOSA, 2014, p. 42). O conhecimento dessas três coisas (a causa primeira, a natureza da mente e a causa dos erros) é, nas palavras de Espinosa, "indispensável para o exato conhecimento" e "somente o ignora aqueles que carecem em absoluto de todo estudo e disciplina" (ESPINOSA, 1988, p. 82). Duras palavras! Espinosa não se detém apenas no anúncio dos erros alheios, ele dá exemplos de como estes erros se tornam manifestos na teoria de Bacon e Descartes. No caso de Bacon, Espinosa parafraseia os aforismos XLI, XLVIII, XLIX e LI do primeiro livro do Novum Organum resumindo- os em três conjuntos de crenças que exemplificam os erros cometidos pelo Barão de Verulam: (1) a suposição de que o entendimento humano erra por sua própria natureza, pois, tudo concebe segundo a sua imagem e não segundo a imagem do universo, (2) a crença de que o intelecto por sua própria natureza tende ao abstrato e finge ser fixo o que na verdade é cambaleante, e (3) que a vontade humana é livre e mais ampla que o próprio entendimento e que por isso ele não é uma luz pura, antes, sofre interferência da vontade e dos afetos. Se, conforme explica Lívio Teixeira, para Espinosa todos os erros que os filósofos comentem envolvem algum nível de abstração, então, nosso filósofo, ao caracterizar como errada a crítica baconiana à abstração, acaba por apontar que a própria crítica de Bacon é uma abstração. Engenho!

Diante do que foi exposto podemos perguntar em que Espinosa se distingue dos filósofos citados quanto ao tema da abstração. Acreditamos que tal distinção ocorre porque para nosso filósofo a abstração não consiste apenas no ato de separar e fragmentar os objetos do conhecimento e não é o mero estabelecimento arbitrário de princípios para conhecimento graças à interferência da vontade no intelecto. Antes, nossa hipótese é que para Espinosa a abstração ocorre quando uma força produtiva da mente não se encontra enquanto tal; em outros termos: quando a mente não tem 
consciência do seu próprio produzir - é precisamente isso o que chamamos de abstração de si. Assim, se nas formulações presentes na Lógica de Port-Royal e no Novum Organum, o problema da abstração aparece como um problema na relação sujeito e objeto, acreditamos que em Espinosa a abstração possui sua origem na relação do indivíduo consigo mesmo? Para melhor fundamentar tal hipótese resolvemos dividir o texto a seguir da seguinte maneira: primeiro, começaremos com um panorama a respeito do tema da abstração na obra de Espinosa; depois entramos no tema da abstração de si; por fim, nós daremos um exemplo de como opera a crítica espinosana à abstração de si. Dessa maneira, nós partiremos do mais abrangente (a análise geral) até o mais concreto (um caso exemplar na obra de Espinosa, o TTP). Prossigamos.

\section{O tema das abstrações na obra de Espinosa}

Em toda a sua obra Espinosa faz trinta e três menções diretas ao termo abstração ou a algum termo derivado do radical latino abstrac. Tais menções se distribuem em sua obra da seguinte maneira: quatorze delas estão no TIE, onze na correspondência de Espinosa (uma na Carta II, oito na Carta XII e duas na Carta XIX), uma no KV, cinco na Ética e, por fim, mais duas menções no TP. Além das já citadas, há mais uma no prefácio que Ludovicus Meyer fez para o Principiorum Philosophie. Entretanto, a abordagem do tema das abstrações não se limita às já citadas menções. Podermos avaliar a importância deste tema dentro da filosofia espinosana recorrendo ao levantamento feito por Samuel Newlands sobre os diversos temas que, segundo o comentador, aparecem relacionados a ele na obra espinosana:

A visão materialista da alma (TIE §74).

O paradoxo de Zenão (carta 12).

Teoria da privação do Mal (carta 19).

Concepções destorcidas sobre a providência e o conhecimento Divino (KV I, 6; CM II, 7).

Falsa concepção da física mecânica (carta 12).

Concepções distorcidas da liberdade e da vontade hu-

\footnotetext{
${ }^{9}$ Isso implica dizer que há um certo nível de autorreferência na questão da abstração em Espinosa - o que não nos parece absurdo diante do que é exposto no KV no Primeiro Diálogo quando a Razão responde para a Concupiscência que "o entendimento é a causa de suas ideias [...], pois que suas ideias dele dependem. E, de outro lado, um todo, tendo em vista ser composto por suas ideias" (ESPINOSA, B. 2014, p. 65). Isto é, o entendimento não produz seus conteúdos como realidades externas, não há cisão entre o produzir e o produto do agir mental. Essa identidade entre o entendimento como produtor de suas ideias e o entendimento como a totalidade de suas ideias nos permite dizer que há uma espécie de "refluxo" sobre o indivíduo quando este produz ideias abstratamente. Supomos que a superstição seja uma das manifestações desse "refluxo".
} 
mana (KV II, 16; carta 2; E II P49s).

Falsas concepções acerca da perfeição e da imperfeição (E IV prefácio).

O problema do Mal (KV, I, 6; E I apêndice; E IV prefácio).

Formas de antropomorfismo teológico (E I apêndice).

$\mathrm{O}$ conceito de faculdades psicológicas (KV II, 16; E II P48s; E II P49s).

Os afetos de culpa, louvor e mérito ( $\mathrm{E}$ I apêndice).

Estética objetiva (E Iapp, G 2:82);

Teleologia divina ou natural (E I apêndice).

Realismo Moral (CM I, 6; KV, I, 10; KV, II, 4; KV, I, 6; E IV prefácio).

Ceticismo (E I apêndice).

(NEWLANDS, S. 2015, p. 74-5)

O levantamento realizado por $\mathrm{Ne}$ wlands revela que temas caros à Espinosa (como a crítica ao livre-arbítrio, à teleologia e ao antropomorfismo) são, na verdade, consequências e desdobramentos das críticas erigidas pelo filósofo contra as abstrações. Embora seja assim, o primeiro grande estudo dedicado ao tema das abstrações na filosofia de Espinosa só veio a ser realizado na segunda metade do século XX. Trata-se da tese de livredocência de Lívio Teixeira apresen- tada ao departamento de filosofia da Universidade de São Paulo em 1953 - um marco histórico nos estudos sobre a filosofia de Espinosa. Sob o título A doutrina dos modos de percepção e o conceito de abstração na filosofia de Espinosa, a tese de Lívio não era pioneira apenas por tratar do tema das abstrações, mas por apresentar um original e inédito estudo a respeito do Tratado da Emenda do Intelecto. Até então, o TIE era tido por muitos (e ainda é para alguns) como um texto demasiado juvenil no qual Espinosa não expõe propriamente a sua epistemologia, mas a de Descartes. Contudo, Lívio Teixeira mostra que as críticas às abstrações presentes no TIE são fundamentais para compreendermos a recusa de Espinosa ao dualismo substancial cartesiano e à teoria da faculdade da vontade. O ponto nevrálgico da tese de Lívio Teixeira é a relação que ele mostra haver entre a epistemologia e a ontologia espinosana. Sem este vínculo não é possível entender o âmago do conceito de abstração em Espinosa: o fato de que para o filósofo as ideias abstratas não são apenas entes de razão desprovidos de realidades extramental, mas, também, qualquer conceito concebido à parte do Todo. Lívio comenta: "abstrair é querer compreender a parte sem o todo. Ou melhor, é atribuir realidade ao que é parcial" (TEIXEIRA, L. [1953] 2001, p. 11). Ora, uma vez que o Real para Espinosa consiste em uma única Substância que é causa 
imanente de si mesma, e dado que para o filósofo conhecer é conhecer pela causa (ir das causas aos efeitos), conclui-se que "só podemos conhecer a parte a partir do todo ou integrada ao todo" (idem, ibidem). Ideias são abstratas não porque são mutiladas, confusas e desordenadas, ao contrário, justamente porque são concebidas à parte do Real concreto (o Todo) é que elas serão mutiladas, confusas e desordenadas, isto é, abstratas. Conceber uma ideia abstratamente significa concebê-la fora de suas relações e nexos. Conceber algo fora dos nexos que o constitui significa concebê-lo parcialmente, sem clareza e distinção. Além disso, Lívio Teixeira defende que a teoria dos modos de percepção/concepção realizada por Espinosa no Emendatione, no Breve Tratado e na Ética é "um apelo ao aprofundamento da consciência" que simultaneamente "constitui o processo de eliminação do pensamento abstrato e ao mesmo tempo a identificação da alma humana com a Realidade" (idem, p. 171).

Seguindo a via aberta por Lívio Teixeira, façamos uma breve análise das diversas aparições do tema das abstrações na filosofia de Espinosa. Podemos apreender a visão que Espinosa tem dos conceitos abstratos se tomarmos como exemplo o que o fi- lósofo diz no KV I, 6 (7): "todas as coisas particulares, e somente elas, têm causa, e não as universais, pois estas nada são". Também, no mesmo capítulo do KV, mas agora no $§ 9$, Espinosa toma os conceitos de bem, mal e pecado como abstrações e, por isso, como não sendo "outra coisa do que modos de pensar, e de maneira nenhuma coisas ou algo que tenham existência" (itálicos de Espinosa). Em outra passagem do KV - a nota de rodapé do $\$ 4$ de KV II, 16 - Espinosa fala que os conceitos de vontade e intelecto enquanto faculdades do espírito não passam universais concebidos a partir de abstrações realizadas a partir de volições mentais singulares e, por isso, conclui que enquanto ens rationis "não posso atribuir-lhes nada real". Já nos CM, I, 1, Espinosa diz que gênero, espécie, tempo, número e medida "não são ideias de coisas e de modo algum podem ser colocados entre as ideias; por isso também não têm eles nenhum ideado que exista necessariamente ou que possa existir".

Para Samuel Newlands esses trechos parecem endossar que Espinosa mantém um "stronganti-abstractionism (SAA), 10 (NEWLANDS, 2015 [I], p. 256). Em outros termos: para Newlands esses trechos aparentemente reforçam que para Espinosa as abstrações nada são.

\footnotetext{
${ }^{10}$ Literalmente: antiabstracionismo forte.

11 "(SAA): There are no such things as abstract objects. According to SAA, abstracta do not exist, full stop" (NEWLANDS, 2015 [I], p. 256).
} 
Assim, de acordo com a SAA "não existem coisas como objetos abstratos [...] ponto final" (idem, ibidem $)^{11}$. Assim, o strong-anti-abstractionism se caracterizaria por uma postura meramente eliminativa, tomando as abstrações como meras quimeras ou irrealidades a serem descartadas 12 , Entretanto, em outras passagens do texto espinosano nós encontramos uma posição mais moderada em relação às abstrações, aquilo que Newlands chama de "weak-anti-abstractionism $(W A A)^{, 13}$ (NEWLANDS, 2015 [I] 257). Um dos trechos levantados pelo comentador para reforçar a sua hipótese é a passagem dos Cogitata I, 1. Lá Espinosa usa o exemplo da técnica mnemônica, que consiste em estabelecer relações entre conteúdos mentais diversos, para explicar os universais:

Que haja certos modos de pensar que sirvam para mais firme e facilmente reter as coisas [...] consta-o suficientemente os que utilizam aquela notória regra de memória pela qual, para reter e imprimir na memória uma coisa novíssima, recorre-se a outra que nos seja familiar e que com ela convenha [...]; de modo semelhante [hunc similiter in modum], os filósofos reduziram todas as coisas naturais a certas classes, às quais recorrem quando ocorre-lhes algo novo e a que chamam de gênero, espécie, etc (CM I, 1).

Esse trecho insere-se na parte dos $\mathrm{Co}$ gitata dedicada a explicar o que são os entia rationis (entes de razão) e, em vista disso, Newlands comenta que na perspectiva de um WAA "os objetos abstratos são entidades [entities] dependentes da mente. Mais especificamente, Espinosa pensa que as abstrações são representações confusas de uma mente finita" (NEWLANDS, 2015 [I], 257) ${ }^{14}$. Assim, na leitura de Newlands os objetos abstratos são representações determinadas pelos modos finitos de pensamento[15. A sequência do texto dos Cogitata parece reforçar a tese de $\mathrm{Ne}$ wlands, afinal, Espinosa afirma que quando se indaga o que é uma espécie nada mais busca-se "do que a natureza deste modo de pensar, que é deveras um ente e distingue-se de

\footnotetext{
12 Outras passagens parecem endossar uma posição do tipo SAA, por exemplo Espinosa no §99 do TIE escreve que "é necessário, desde o início, sempre deduzir nossas ideias [...] a partir de um ente real para outro ente real, de modo que seguramente não passemos a ideias abstratas e universais [...] pois interrompem o verdadeiro progresso do intelecto".

${ }^{13}$ Literalmente: antiabstracionismo fraco.

14“"(WAA): Abstract objects are mind-dependent entities. More specifically, Spinoza thinks abstracta are confused representations of a finite mind" (NEWLANDS, 2015 [I], 257).

15 "In Spinoza's preferred ontology, abstract objects are the representational contents of particular finite modes of thinking" (NEWLANDS, 2015 [I], 257).
} 
outro modo de pensar; esses modos de pensar, contudo, não podem ser chamados de ideias nem podem ser ditos verdadeiros ou falsos" (CM, I, 1). Além disso, Espinosa distingue a ficção da abstração ao afirmar que um ente de razão não "depende só da vontade e nem consta de termos conectados entre si" (idem, ibidem). Vinculando isso com o $§ 93$ do TIE no qual Espinosa fala que devemos nos acautelar e nunca concluir algo a partir de abstrações ao tratarmos da inquisição das coisas, evitando, dessa maneira, confundir o que está somente no nosso intelecto com o que está na coisa - Samuel Newlands caracteriza o weak-anti-abstractionism (WAA) como sendo uma preocupação de Espinosa sobre os efeitos de pensarmos abstratamente ao investigarmos a natureza; a dizer, a reificação da abstração no conteúdo da investigação ${ }^{16}$.

Embora a interpretação de $\mathrm{Ne}$ wlands seja riquíssima ${ }^{17}$, há alguns pontos que é útil lembrar ao lidarmos com os textos do Cogitata: primeiro, Espinosa mantém-se próximo da linguagem cartesiana, como pode-se notar pela referência à vontade. Além disso, Espinosa define o ente de razão como "um modo de pensar que serve para mais facilmente reter, explicar e imaginar as coisas entendidas" (idem, ibidem - itálico nosso), e não como "representações confusas" , como afirma Newlands. A respeito da ideia de representação vale ressaltar que Espinosa é contrário a tal concepção. De fato, na Ética Espinosa se refere à ideia como "conceito que a mente forma por ser coisa pensante" (EII, D3 - itálico nosso). Na explicação dessa definição ele acrescenta que usou o termo "conceito" em vez de "percepção" com o objetivo de indicar o caráter ativo da mente. Embora Espinosa diga diversas vezes nos $\mathrm{Co}$ gitata que os entes de razão não são ideias e não podem ser chamados de ideias - afinal toda ideia possui um caráter objetivo e os ens rationis não - ele não fala que os entes de razão são representações. Antes, ele se refere aos entes de razão com a expressão "modum cogitandi" que numa tradução flexível poderia ser chamado de "maneiras de pensar". Assim, os entes de razão se aproximam mais de um modo de operação mental do que de uma representação objetiva. Também é preciso ressaltar que na definição oferecida por Espinosa aos entes de razão no $\mathrm{CM}$ ele fala que eles auxiliam na retenção, explicação e imaginação das "coisas entendidas [res intellectas]" (CM, I, 1). O que o

\footnotetext{
16 "Spinoza's main concern is that thinking abstractly while "investigating nature" often leads to a confused reification of abstracta" (NEWLANDS, 2015 [I], 265).

17 As considerações de Newlands sobre o tema das abstrações em Espinosa são muito importantes na medida em que ele aponta para o processo de reificação da abstração. Além disso, Newlands faz uma inovadora leitura sobre a aplicação que Espinosa faz no campo ético das críticas às abstrações.
} 
nosso filósofo aponta repetidamente nesse primeiro capítulo dos Cogitata é que o erro em relação aos entes de razão está em afirmá-los como entes [ens], isto é, está em confundir uma maneira de pensar com uma realidade objetiva. Neste sentido, é significativo que Espinosa compare os entes de razão com uma técnica mnemônica. A relação estabelecida por Espinosa não é entre tipos de entes (um real e o outro apenas mental); antes, a relação é estabelecida entre uma técnica e o que é comumente chamado de ens rationis. Por fim, Espinosa explica a origem da confusão existente em chamar uma maneira de pensar de ens:

a causa por que esses modos de pensar são tidos como ideias de coisas é que tão imediatamente provêm e originam-se das ideias de entes reais que são facilmente confundidos com elas por aqueles que não atentam mui cuidadosamente [accuratissimè attendum]; donde também lhes terem imposto nomes como se para significar entes que existem fora de nossa mente, e chamando tais entes, ou antes, não entes, de entes de razão (idem, ibidem).

A causa da confusão está no fato de confundir o processo com o proces- sado. Aqueles que não attendum accuratissimè tendem a cometer o erro denunciado no $\$ 93$ do TIE: misturar aquilo que está somente no intelecto (processo) com aquilo que está na coisa (processado). A esta confusão acrescenta-se mais uma, originária não apenas da falta de uma cautelosa atenção, mas, também, da dilatação linguística: atribui-se nomes aos processos mentais da mesma maneira que se nomeia coisas. Essa dupla confusão permite não apenas o total desconhecimento da natureza da atividade mental quanto a sua reificação numa suposta coisa independente: um suposto ente. Assim, embora discordamos de Newlands quando ele chama as abstrações de representações confusas da mente finita, concordamos com ele quanto ao fato do processo de abstração envolver uma reificação. Entretanto, a respeito deste último ponto gostaríamos de acrescentar que a reificação não ocorre apenas no uso das abstrações (por exemplo nas ciências "ao lidarmos com as coisas naturais"), mas, sobretudo, a própria produção de conceitos abstratos envolve um processo de reificação. Nossa hipótese é que os próprios conceitos abstratos são reificações de processos mentais na categoria geral de ente. Reificação essa que só é possível mediante o apagamento do caráter produtivo (e, portanto, causal) das ideias. Isso evidencia porque Espinosa diz que da mesma maneira que a técnica mnemônica é apenas uma 
maneira de pensar e organizar os dados de nossa memória, assim também as classificações como gêneros, espécies etc, são modos de pensar. Tomados sob esse prisma, os universais, os gêneros e as espécies não passariam de associações mentais arbitrárias ${ }^{18}$ 19 — não são coisas, mas operações mentais.

No entanto, para ficar mais evidente o ponto levantado tomemos em consideração outro trecho da obra de Espinosa em que o filósofo fala sobre o tema das abstrações: a nota $h$ do $\$ 21$ do TIE. Lá o filósofo explica que quando chegamos às conclusões de maneira abstrata é preciso sermos maximamente cautelosos [caventibus]. Espinosa informa que tais conclusões, ainda que sejam verdadeiras, "não estão suficientemente protegidas" contra confusões. Que tipo de confusões? Espinosa explica: aquilo que os homens concebem abstrata, separada e confusamente, "eles impõe nomes, os quais já são usados por eles para significar outras coisas mais familiares, o que faz com que aquelas coisas sejam imaginadas do mesmo modo que estas" (TIE, §21 nota - itálicos nossos). Gostaríamos de focar apenas um aspecto dessa nota: a referência à linguagem. Espinosa afirma que os homens atribuem aos conceitos abstratos os mesmos nomes que usaram para significar coisas que lhes são familiares [res familiaria]. Deste modo, a nota $h$ parece solidária do Cogitata ao afirmar que há uma transposição do campo das abstrações para o campo das coisas quando se nomeia as primeiras da mesma maneira que as últimas. Assim, podemos afirmar que quando o campo semântico que discursa sobre coisas [res] passa a ser usado para referir-se às abstrações ocorre um mascaramento das próprias abstrações, que se ocultam sob o manto supostamente límpido da linguagem que discursa a respeito das coisas.

Acreditamos, também, que essa confusão, ou melhor, transposição de um conjunto de signos (palavras que versam sobre coisas) para um campo diverso (o campo semântico das operações mentais) explica a primeira parte da nota $h^{20}$. Antes de tudo, devemos nos lembrar que os nomes são signos que pertencem ao campo da imaginação; além disso, sabemos que a razão (conforme o exemplo da

\footnotetext{
18 Que o leitor não confunda arbitrário com livre-arbítrio ou como associações estabelecidas pela vontade (o que aproximaria Espinosa de Bacon). Arbitrário aqui é tomado em seu sentido mais fraco: como algo que não necessariamente possui correspondência com os entes extramentais.

19 Ora, uma vez que as associações são dependentes de semelhanças, os universais tendem às generalidades abstratas que não conseguem alcançar singularidades. Isso parece ser reforçado pelo que Espinosa no TIE $\$ 93$ quando conclui que "a partir tão somente dos axiomas universais, o intelecto não pode descer às coisas singulares". Assim, cruzando a passagem do CM com o $\$ 93$ do TIE podemos entender o que foi dito em KV I, 6 (7) a respeito de que somente as coisas particulares possuem causa e as universais não: é que somente as coisas singulares são de fato realidades existentes fora da mente, isto é, são coisas.

${ }^{20} \mathrm{O}$ início da nota $h$ diz que os homens no uso da razão "se não se acautelam, incidirão imediatamente em erros; pois, quando se concebem as coisas assim abstratamente e não pela verdadeira essência, são imediatamente confundidos pela imaginação".
} 
quarta proporcional nos $\$ 23$ e $\$ 24$ do TIE) muitas vezes opera pelo mero cálculo sobre os signos sem se dar conta dos verdadeiros processos mentais que estão envolvidos em tal ação. Sobre esse ponto vale retomar aqui brevemente as considerações de Cristiano Rezende em seu artigo $\mathrm{Os} P e$ rigos da Razão Segundo Espinosa: a inadequação do terceiro modo de perceber no tratado da emenda do intelecto. $\mathrm{O}$ comentador argumenta que a razão abre chancela para a abstração na medida em que opera de maneira meramente mecânica. Apoiando-se no exemplo dado por Espinosa no \$24 do TIE a respeito da quarta proporcional, Cristiano Rezende conclui que "a razão realiza certas operações lógicas sem que, no entanto, sejam realmente efetuados todos os atos mentais em que se baseiam os sinais" (REZENDE, C. N. 2004 p. 111). Este operar às cegas pode degenerar-se em mera "técnica teórica" aplicada de maneira generalizada e indistinta a qualquer objeto. Para Cristiano, Espinosa diz que a razão opera de maneira não adequada justamente porque:

a maneira racional de conhecer, à diferença da intelectual, corre o risco de limitarse à aplicação externa de um instrumento de cálculo, de utilidade inquestionável mas, em essência, indistinta de um competente trabalho administrativo sobre um "jogo de signos". Portanto, o verdadeiro perigo, [...] é que a razão se tome e se dê por autônoma, limitando a percepção a essa capacidade de supervisionar o mundo, então reduzido ao objeto $\mathrm{X}$ das operações racionais (idem, ibidem).

Para o comentador essa operatividade da razão pode desdobrar-se numa postura fetichista na qual a pessoa se entreteria mais com a eficácia das operações racionais do que com o próprio estar no mundo, o que redundaria na pessoa deixar de "juntar-se ao mundo através de suas construções" (idem, p. 112). Em suma, Cristiano Rezende diz, dando um sentido espinosano para a frase de Merleau-Ponty, que a percepção reduzida à sua forma meramente racional desemboca "numa ciência que manipula as coisas sem habitá-las" (idem, ibidem). Assim, atribuir às abstrações um campo semântico cujo o uso comum é direcionado às coisas pode, em última instância, abrir margem para as confusões da imaginação, já que a razão ao atuar com signos tende a operar de maneira meramente calculativa.

A nota $h$ do TIE nos lembra outro texto, além dos Cogitata e escrito posteriormente a ambas as obras: o Compêndio de Gramática Hebraica. Espinosa dedica o capítulo $\mathrm{V}$ de sua gramática para explicar o que são nomes: "por nome entendo uma pala- 
vra pela qual significamos ou indicamos algo que cai sob o entendimento" (ESPINOSA, B. 2014, p. 418). Na sequência Espinosa faz uma ressalva: nem tudo o que cai sob o entendimento são coisas, mas, também "atributos de coisas, modos e relações, ou ações e modos de relações de ações" (idem, ibidem). Sendo assim, a linguagem possui uma dilatação maior do que o campo próprio das coisas. Disso a preocupação de Espinosa em distinguir o que é um substantivo, o que é um adjetivo, o que é um nome relativo, um particípio, um infinitivo e um advérbio. Espinosa afirma veementemente que um substantivo e um nome próprio só podem ser ditos de coisas singulares - "não podemos indicar senão um indivíduo singular" (idem, p. 419 - itálico nosso). Capítulos a frente Espinosa volta a insistir que substantivos são nomes de coisas, "nomes [...] para indicar as coisas de modo absoluto" (idem, p. 432). Não satisfeito, Espinosa faz uma lista com exemplos nos quais demonstra o que é um adjetivo e o que é um substantivo. Em síntese: em toda a primeira parte do Compêndio Espinosa demonstra uma preocupação atenuada em distinguir o que é um adjetivo e o que é um nome próprio ou um substantivo. Espinosa também alerta que um nome relativo, como adjetivos etc, só faz sentido em relação a algo e, por isso, 'repugna à natureza dos nomes próprios' (idem, ibidem). A partir do
Compêndio podemos conjecturar que na nota $h$, ao afirmar que nós nomeamos abstrações da mesma maneira que nomeamos coisas, Espinosa desejava apontar a tendência de substantivar aquilo que não é e não pode ser qualificado como um substantivo (como é o caso das abstrações).

Há em todos esses textos algo central que até o momento não demos muita atenção: a referência à cautela. Espinosa fala, na supracitada nota $h$, que a confusão ocorre aos que não são "maximamente cautelosos [maximè caventibus]"; nos Cogitata ele fala que isso ocorre aos que não attendum accuratissimè. Isso indica que tais confusões, que redundam na afirmação de conceitos ou termos abstratos, podem ser evitadas por meio da cautela e da atenção ao operar mentalmente de determinada maneira no caso dos Cogitata ao fazer associações mentais e no caso do TIE ao proceder de maneira analítica indo dos efeitos para a causa. Esse ponto nos interessa, pois acreditamos que toda abstração envolve um certo desconhecimento de si. Nossa hipótese é que para Espinosa os problemas originários no uso dos conceitos abstratos não se estabelecem de maneira imediata na relação de um suposto sujeito e um objeto, antes, eles são originários do fato de aquele que se coloca como sujeito não se perceber enquanto produtor das abstrações. Assim, abre-se uma fenda entre o agir mental deste indivíduo e o produto dessa ação de 
tal maneira que aquele que produz as abstrações não tem consciência plena de seu próprio produzir e nem dos resultados de sua produção. É precisamente isso que chamamos de abstração de si. E é este o próximo foco de nossa atenção.

\section{Há abstração de si na origem de toda abstração?}

Até onde sabemos nenhum comentador da obra de Espinosa usou a expressão abstração de si, no entanto, a tradição interpretativa já trabalha e indica a presença deste tema na filosofia espinosana há um certo tempo. Em seu Nervura do Real, Marilena Chaui ressalta que, para Espinosa, uma vez que somos partes de uma causalidade imanente, nossa mente é concebida como vis nativa e espontânea para o conhecimento (CHAUI, M. 1999, p. 83). Isso significa que nossa mente, na medida em que é partícipe do agir da Realidade, age por si mesma segundo a sua necessidade interna e as conexões entre as suas ideias; ou seja, a mente é, nas palavras de Espinosa, um "automa spirituale". Chaui chama a nossa atenção para as seguintes palavras de Espinosa no Breve Tratado: "chamo o Intelecto de causa, enquanto é causa de seus conceitos (ou enquanto depende de seus conceitos); e o chamo de todo, enquanto constituído por todos os seus conceitos" (ESPINOSA, B. 2012 p. 65). À guisa dessas pala- vras, Chaui comenta:

nossa mente é uma potência pensante que causa a suas próprias ideias e as articula com outras ideias [...]. Ideias são, pois, acontecimentos mentais que, quando verdadeiras ou adequadas, são atos intelectuais que põem sua própria necessidade tanto quanto à sua gênese como quanto aos seus efeitos e às relações com outras ideias, afirmando o movimento e o trabalho do pensamento que somos e no qual estamos (CHAUI, M. 1999, p. 88 - itálicos nossos).

Como acontecimento mental uma ideia é originária na atividade interna à própria mente na qual também participa efetivamente. Nas palavras de Chaui a atividade mental consiste em compreender a gênese das afecções corporais, as relações necessárias entre os corpos, a gênese de suas próprias ideias e as conexões necessárias entre elas de tal maneira a apreender os nexos que constituem a realidade inteira e as essências singulares por ela produzidas (idem, ibidem). É a partir da compreensão dos nexos que constituem as relações entre os corpos, as relações entre as ideias e a articulação entre corpos e ideias que a mente pode enveredar-se, por assim 
dizer, na nervura do real. Ou seja, $a$ mente pode apreender-se como parte ativa da Realidade. Lívio Teixeira - conforme o que comentamos anteriormente - e Marilena Chaui nos mostram que para Espinosa a mente só pode compreender-se como parte de um Todo no momento em que ela encontra-se em plena identidade consigo mesma. Essa identificação nasce do esforço reflexivo da mente em apreender a sua própria gênese e a gênese de suas ideias. O coração dessa via interpretativa está em mostrar que na filosofia espinosana o caminho reflexivo consiste simultaneamente na saída das abstrações e na descoberta da mente como partícipe da atividade do Real concreto o que poderíamos chamar de saída de uma condição propriamente abstrata na qual o próprio homem se concebe à parte da realidade e do Todo. Assim, cruzando (I) a tese de Lívio Teixeira, na qual a abstração consiste em considerar a parte fora do todo; (II) os comentários de Marilena Chaui, que mostram que a superação da abstração é a verdadeira entrada da mente na nervura do real, isto é, o seu encontro consigo mesma como parte da atividade do Real; (III) os trabalhos de Cristiano Rezende, nos quais evidencia-se que para Espinosa a abstração envolve a construção de uma racionalidade meramente instrumental e incapaz de compreender todos os atos mentais implicados em seus cálculos; e, por fim, (IV) as pesquisas de Newlands, que demonstram que o processo de abstração envolvem a reificação dos conteúdos meramente mentais; qual é a conclusão? Pelo prisma dessas interpretações a abstração não é apenas uma ideia confusa e mutilada, mas, sobretudo, um processo que reflui sobre o indivíduo e envolve uma perda de si mesmo. Seja uma perda enquanto parte do Todo (Lívio Teixeira e Marilena Chaui), seja uma perda em relação à consciência de suas próprias atividades mentais (Cristiano Rezende e Samuel Newlands). Acreditamos que tal interpretação possui lastro no próprio texto espinosano.

Em nossa análise do texto espinosano nós frisamos a repetida expressão espinosana "da mesma maneira" (eodem modo no TIE e hunc similiter in modum no CM). É muito curioso que em vários dos momentos que Espinosa explica o processo de abstração ele usa exemplos de outros processos mentais que operam " $d a$ mesma maneira". Nos dois casos aqui citados (a formação dos conceitos de espécie e gênero no $\mathrm{CM}$ e o ato de nomear na nota $h$ do TIE) Espinosa usa exemplos comuns e cotidianos. Assim, Espinosa parece vincular a abstração a uma atividade banal e sem grandes mistérios (o ato de nomear, calcular uma regra de três ou uma técnica mnemônica). A diferença entre essas ações comuns e as abstrações não nos parece estar associada aos processos dessas atividades. A dis- 
tinção entre a técnica mnemônica e a formação dos gêneros, por exemplo, não parece encontrar-se na lógica operativa pela qual cada um desses processos ocorrem. Antes, ela parece residir no grau de consciência que a pessoa tem a respeito do seu próprio agir mental. Um gênero é formado hunc similiter in modum à técnica mnemônica. Nomeia-se um conceito abstrato da mesma maneira que nomeia-se uma coisa. A diferença, porém, é que aquele que aplica e técnica de associação mental das memórias sabe que fez tal associação e, em consequência sabe que ela é arbitrária e não algo que exista fora de sua mente. Ocorre o mesmo com aquele que nomeia algo $e$ sabe o que nomeou; ainda mais, sabe o que é nomear e que tipo de nome dar de acordo com o que se nomeia. Por outro lado, aquele que concebe abstratamente "vive quase inconsciente de si, de Deus e das coisas" (E $\mathrm{V}, \mathrm{P} 42$, sch. $)^{21}$, Ou seja, não sabe que os gêneros são frutos de seu labor mental, não sabe o que nomeia e nem sabe nomear. $\mathrm{O}$ mais trágico é que este não saber permite a reificação do labor mental numa abstração que aparece para o indivíduo como coisa real, desconectada dele e a ele revelada. Quando operamos de maneira abstrata confundimos os frutos de nosso trabalho mental com descobertas que aparecem como independentes de nós e existentes em si mesmas. A abstração envolve um modo de produção no qual a causalidade imanente é apagada em detrimento de uma causalidade transitiva que pende para o transcendente de tal maneira que produtor e o produzido não se identificam. Aliás, essa é a marca da causalidade transcendente: a cisão irremediável entre causa e efeito.

A urgência de um autoconhecimento aparece diversas vezes no TIE. No $\S 105$ do TIE, Espinosa escreve que o método para se chegar ao conhecimento das coisas eternas é reflexivo e consiste em conhecer o próprio intelecto: suas forças e suas propriedades. Também, no mesmo parágrafo, Espinosa fala que este autoconhecimento por parte do intelecto é $O$ meio para a aquisição do fundamento a partir do qual "deduziremos nossos pensamentos na medida em que nossa capacidade suporta”. No $\$ 25$ TIE o primeiro ponto levantado por Espinosa para alcançar o "nosso fim", aquele que se encontra no $\$ 13$ do TIE (o "conhecimento da união que a mente tem com a Natureza inteira" que é também a saída da abstração), é: “(i) Conhecer exatamente a nossa natureza, que desejamos aperfeiçoar e, simultaneamente, da natureza das coi-

\footnotetext{
${ }^{21}$ É importante lembrarmos que quando Espinosa critica Descartes e Bacon à Oldemburg na Carta II ele fala que ambos os filósofos encontram-se em situação relativamente próxima da citada neste escólio: "o primeiro e maior erro de ambos consiste em que estão muitíssimos distanciados de conhecer a primeira causa e a origem de todas as coisas [Deus]. A segunda é que não conhecem verdadeiramente a natureza da alma humana [inconsciência de si]" (ESPINOSA, 2014, p. 42).
} 
sas quanto seja necessário" (TIE, §25 - itálicos nossos). De outro modo: sair da abstração e conhecer a união que a nossa mente tem com a natureza inteira envolve necessariamente e em primeiro lugar "conhecer exatamente nossa natureza" (idem, ibidem). Também, no mesmo sentido, o §16 do TIE afirma: "antes de tudo [ante omnia], porém, há de se excogitar um modo de remediar o intelecto e expurgá-lo, o quanto permite o início, para que ele intelija as coisas com felicidade, sem erro e da melhor maneira". Na sequência Espinosa fala que para realizar tal intento faz-se necessário "que eu resuma aqui todos os modos de perceber de que até agora dispus para afirmar ou negar algo [...] para que eu eleja o melhor de todos e simultaneamente comece a conhecer minhas forças e natureza, que desejo aperfeiçoar" (TIE, §18 - itálico nosso). Se nos textos em que Espinosa trata da abstração ele faz referências aos que não são cautelosos, não prestam atenção e não conhecem a natureza do intelecto, nos textos em que ele propõe a maneira de sair da abstração ele sempre exorta o retorno a si na busca do autoconhecimento.

Para acrescentar um exemplo a respeito de quão determinante é o conhecimento de si nós citaremos, ainda que brevemente, a questão das hipóteses em Espinosa. Acreditamos que é o autoconhecimento, ou melhor, o conhecimento reflexivo, o que impede a hipótese de ser classificada no $\$ 57$ do TIE como mera abstração. Vejamos.

Cristiano Rezende comenta que o estatuto epistêmico das hipóteses era algo em disputa no século XVIL 2 . A tradição havia caracterizado as hipóteses como um tipo de proposição da qual não é possível, num primeiro momento, haver demonstração e que estabelece ou não o ser de algo. Originária da palavra $i \pi o ́ \theta \varepsilon \sigma \iota \varsigma$, do grego antigo, 'hypóthesis' (transliteração) é formada pela união de 'hypo' ('sob', 'abaixo de') e 'thésis' ('posição'). Assim, uma 'hypothesis' caracterizase pelo ato de fazer deduções concisas a partir da ação de colocar algo sob [hypo] uma certa perspectiva intelectual [a thesis] - perspectiva essa que só pode ser intelectual, pois não há como realizar experimentos daquilo que não é efetivo, mas contrafactual. Nos seiscentos, porém, as hipóteses haviam sido reduzidas ao instrumentalismo. O exemplo máximo disso encontra-se na disputa entre teólogos e cientistas com relação à validade das hipóteses do De Revolutionibus Orbium Coelestium de Copérnico. Andreas Osiander, em vistas de abrandar os teólogos, inseriu apocrifamente no Revolutionibus um prefácio no qual dizia: "não é necessário que essas hipóteses sejam verdadei-

\footnotetext{
${ }^{22}$ Cf. REZENDE, Cristiano N. O Estatuto das Hipóteses Científicas na Epistemologia de Espinosa. Cadernos de História de Filosofia e Ciência, Campinas, Série 3, v. 18, n. 1, jan.-jun. 2008. p. 147-71.
} 
ras, e nem mesmo verossímeis, bastando apenas que forneçam cálculos que concordem com as observações" (OSIANDER, A. apud REZENDE, 2018 , v. 18, p. 150) Dessa maneira, a questão que surge a respeito das hipóteses pode ser sintetizada da seguinte forma: seriam elas apenas um instrumento abstrato, sem compromisso com o conhecimento da realidade; ou, estariam elas de acordo com a 'norma da verdade', isto é, capazes de proporcionar aos homens conhecimentos verdadeiros? Espinosa estava consciente dessa discussão, prova disso é que ao tratar das hipóteses no TIE ele faz referência ao tema copernicand 24 . Faz-se necessário perguntar: o que nos fala Espinosa sobre as hipóteses? No §57 do Emendatione, Espinosa começa por definir o que é uma quimera e o que é uma ficção; somente após isso é que ele dedica-se a tratar da hipótese. Ao fazer isso, a primeira coisa que o filósofo estabelece são as fronteiras entre as duas primeiras e a última 25 . Disso uma conclusão é imediata: uma hipótese não é uma quimera e não é uma ficção e, portanto, não pode ser uma ferramenta de caráter meramente ficcional. Entretanto, essa conclusão não protege a hipótese de ser consi- derada uma abstração afinal, como vimos no caso dos entes de razão no $\mathrm{CM}$, Espinosa também os distingue da mera ficção e da quimera. Vejamos como prossegue nosso filósofo.

Definida a quimera e a ficção, Espinosa fala no $\$ 57$ do TIE que tratará das "questões supostas, o que por vezes também acontece a propósito de impossibilidades", isto é, das hipóteses. Espinosa recorre então ao exemplo da vela 'ardente que não arde'. Ele propõe então duas suposições hipotéticas nas quais uma vela, ainda que flamejante, perdura sem se consumir: (I) quando dizermos "suponhamos que esta vela ardente não arde agora" (idem, ibidem - itálicos nossos), isto é, quando trazemos à mente a ideia de uma outra vela não acesa; (II) quando, ao contrário, falamos "suponhamos arder em algum espaço imaginário ou onde não se dá corpo algum" (idem, ibidem). À primeira vista essas duas suposições encaixam-se como a mão e a luva naquilo que poderíamos chamar de processos abstratos ou de abstração. De fato, no primeiro caso substitui-se uma coisa real, um ente, por uma coisa imaginária. Por sua vez, no segundo caso abstraimos algo das diversas relações concretas que

\footnotetext{
${ }^{23}$ Como o próprio Osiander posteriormente assumiu em carta "os teólogos serão facilmente abrandados se lhes for dito que [...] que essas hipóteses são propostas não porque de fato são verdadeiras, mas porque regulam a computação do movimento aparente". O trecho da carta se encontra traduzido para português na introdução que Zeljko Loparic fez para sua tradução do "Prefácio" de Andreas Osiander publicado nos Cadernos de História e Filosofia da Ciência, v. 1, n.1, pp. 44-61, 1980.

24 Cf. TIE §56-7.

${ }^{25}$ O mesmo que ele fez no CM ao definir o que era os "entes de razão", primeiro ele distinguiu o que é uma quimera e uma ficção (cf. CM I, 1).
} 
ele estabelece imaginando-o em um espaço imaginário no qual nada lhe afeta. Nada poderia ser mais abstrato do que esses dois casos. Entretanto, Espinosa faz a seguinte observação: "embora claramente se intelija que esta última é impossível; mas, quando isso se faz absolutamente nada é fingido" (idem, ibidem - itáli$\cos$ nosso) ${ }^{26}$. Embora tal experimento seja fisicamente impossível, pois ele supõe mover a vela para um espaço no qual ela não esteja circuncidada de corpos, "nada é fingido". A primeira pergunta que nos vem à mente é: por que nada é fingido? A primeira parte da resposta a essa pergunta é evidente: "sabe-se que é impossível". De saída já estamos de posse do conhecimento a respeito da impossibilidade real de tal experimento que, justamente por isso, só pode ser mental. A segunda parte da resposta é que a inteligibilidade a respeito do que é vela e o conhecimento das leis de inércia garantem que, em um espaço no qual não exista nada que a impeça de continuar na existência, a vela perduraria sem consumir-se (cf. CHAUI, M. 2016, p. 24). Desta maneira, Espinosa desloca o problema da correspondência entre o conteúdo de uma hipótese e alguma realidade para a construção intelectual de uma experiência. Embora uma hipótese seja um experimento realizável apenas no nível mental, ela não é mera abstração ou ficcionismo instrumental. Isso porque ela opera a partir do conhecimento que o indivíduo possui tanto de si quanto a respeito da coisa sobre a qual ele formula a hipótese. Além disso, a hipótese inclui o conhecimento das leis da natureza. Uma hipótese não nasce do encontro fortuito da mente com as coisas - como se ela fosse aprendiz delas - , antes, ela origina-se da ação do intelecto que atua como juiz que julga a partir de suas regras e do conhecimento prévio de como algo se comporta em situações diversas (Cf. REZENDE, C. 2008. p. 147-71). No exemplo das velas, o ponto cardeal é que em ambos os casos temos uma ideia clara e distinta da vela e é justamente por isso que podemos tanto movê-la para o espaço imaginário, quanto alterar racionalmente suas características, tirando disso conclusões acertadas (CHAUI, M. 2016, p. 24). Pois, como nos explica Chaui, temos a construção de "uma essência em sua inteligibilidade de tal maneira que ela permita deduções ordenadas e, por conseguinte, bem fundamentadas" (idem, ibidem). Enquanto a abstração envolve o desconhecimento de si e a confusão do

\footnotetext{
${ }^{26} \mathrm{O}$ tom usado aqui por Espinosa nos lembra Galileu Galilei que, ao tratar das hipóteses referentes à queda de uma bola de canhão perpendicular a um mastro de navio em movimento, coloca na boca da personagem Salviati as seguintes palavras emblemáticas: "Eu, sem experiência, estou certo de que o efeito seguir-se-á como vos digo, porque assim é necessário que se siga”. GALILEU, Galilei. Diálogo sobre os dois máximos sistemas do mundo - ptolomaico e copernicano. Trad. Pablo Rubén Mariconda. $3^{\circ}$ ed. Editora 34, São Paulo, 2011. p 226.
} 
que há em nossa mente com o que constitui a essência de algo, a hipótese, justamente porque "sabe-se", é, para Espinosa, originária da potência da mente em compreender a essência singular das coisas e, também, em deduzir seu comportamento em espaços ou condições imaginárias. Por isso, como comenta Cristiano Novaes Rezende, uma hipótese é uma ideia verdadeira...

quando inserida no processo regular e contínuo no qual a mente não é determinada de fora, isto é, determinada pelo encontro fortuito das coisas e com as coisas, as quais por si mesmas não nos levam a considerar umas de preferência a outras. A hipótese é uma ideia verdadeira quando a mente não funda a verdade nos fenômenos, mas sim em si própria, isto é, quando a mente se determina desde de dentro ao mesmo tempo em que vai ao encontro dos objetos da experiência" (REZENDE, C. N. 2008, p. 165).

Sendo assim, podemos concluir que a hipótese é uma ideia verdadeira quando não opera a partir da abstração de si, quando sua formulação é acompanhada de um duplo conhecimento: (I) o conhecimento de si, isto é, da força e natureza do intelecto, e
(II) o conhecimento da essência objetiva sobre a qual opera.

Em suma: seja nos Cogitata, seja no TIE (para não citarmos as outras obras de Espinosa) a abstração sempre vem acompanhada da ideia de uma perda de si, uma ignorância em relação a si mesmo. Em sentido contrário, no KV Espinosa chama o momento em que a mente descobre a si mesma como potência para o verdadeiro de "renascimento", pois "sem a soberania do entendimento, tudo se encaminha para a perda, sem que possamos gozar de qualquer descanso, vivendo como se estivéssemos fora de nosso elemento" (KV, II, 26).

\section{Um exemplo de como opera a crí- tica espinosana à abstração de si: a abertura do Tratado Teológico- Político}

O leitor há de estranhar que escolhemos justamente o TTP para servir de exemplo, afinal esta é a única obra em que Espinosa não faz referência direta ao tema abstração. Entretanto, pretendemos mostrar que as considerações a respeito das abstrações sustentam algumas teses de Espinosa no seu polêmico tratado. Para demonstrar isso nós analisaremos a primeira frase do prefácio do TTP. Há três aspectos dessa sentença inicial que consideramos serem os mais importantes: (1) trata-se de uma proposição condicional negativa que se estrutura 
à maneira de uma hipótese; (2) ela é referente à natureza humana e às relações que essa natureza estabelece no mundo; (3) trata-se uma sentença com efeito retórico que corrói uma imagem abstrata do homem ${ }^{27}$.

Espinosa abre o TTP com a seguinte proposição: "se os homens pudessem, em todas as circunstâncias, decidir pelo seguro ou se a fortuna se lhes mostrasse sempre favorável, jamais seriam vítimas da superstição" (ESPINOSA, B. 2003, p. 5)". O "se" inicial nos coloca diante de uma proposição condicional e negativa. Marilena Chaui comenta que "Espinosa critica indiretamente os medievais e Descartes, reescrevendo as teses que combate na forma de orações hipotéticas (se... então), retirando das hipóteses conclusões que as negam" (CHAUI, M. 1974, p. 56). A comentadora ressalta que esse procedimento é tão constante em Espinosa que quase poderíamos tomá-lo como norma de leitura: "as orações hipotéticas apresentam teses que não são espinosanas, que são levadas à autodestruição no decorrer da argumentação" (idem, ibidem) ${ }^{28}$, Assim, a abertura do TTP é polêmica: primeiro, porque, conforme veremos, ela retoma a imagem do homem que foi tecida pela tradição teológica; em segundo lugar, essa retomada dá-se no seio de uma hipótese negativa, ou seja, tal imagem é tomada como esvaziada de realidade. Acreditamos ser este o cerne da hipótese que abre o TTP.

Em sua tese de doutoramento, Marilena Chaui defende que o termo mais importante da proposição inicial do TTP é a conjunção condicional "se", pois ela abre as duas condições necessárias para a existência da superstição (CHAUI, 1970, p. 134). Ora, em que consistem essas duas condições? Consistem numa mudança ou na natureza humana ou na natureza do mundo, que permitisse aos homens serem iguais à vela ardente que não arde. Se lermos atentamente o enunciado da primeira parte da hipótese na abertura do TTP, notaremos que Espinosa propõe a $m u$ dança imaginária de uma das características dos "homens". Qual? A chave para compreender isso está na palavra latina regere, que na tradução espanhola do TTP, de Atilano Dominguez, foi traduzida por "conducir", na portuguesa, de Diogo P. Aurélio, por "decidir" e na brasileira, de J. Guinsburg e Newton Cunha, por "regrar".

\footnotetext{
27 Conforme veremos, dessas três características seguem-se algumas consequências: (1) a superstição deixa de ser uma característica acidental, já que supressão absoluta da superstição só é possível com uma concepção abstrata natureza humana. (2) Sendo inerente à natureza humana, a superstição deixa de servir como distintiva entre as diversas religiosidades e etnias. (3) Espinosa desvincula o conceito de superstição do mito fundador da moral judaica-cristã, ou seja, do mito da queda original. Ao final, pretendemos deixar evidente a maneira pela qual opera a crítica espinosana às abstrações na abertura do TTP.

28 A mesma chave de leitura é mobilizada pela comentadora ao comentar a abertura do TTP em sua tese de doutoramento: "O prefácio do TTP começa com uma proposição condicional e negativa, característica peculiar de Espinosa todas as vezes em que, para demonstrar a necessidade de um conceito, passa pela hipótese a ser recusada — toda proposição negativa é ausência de definição e, portanto, de realidade" (CHAUI, M. 1970, p. 133).
} 
Embora distintos uns dos outros, cada vocábulo escolhido nessas traduções ressalta aspectos daquilo que constitui o poder regencial: poder de decisão, de condução e de regulação. Originária do campo político, regere é a forma no infinitivo presente do verbo latino rego, que tem sentido de regência. Reger é ter o dominium ${ }^{29}$ sobre os assuntos internos de um imperium. A abertura do TTP alude a um poder regencial que redunda num "certo consilio" sobre "res omnes suas"; alude, potanto, para uma deliberação certa sobre todas suas coisas. É muito interessante que essa forma de regência impõe a exterioridade já que "a deliberação supõe exterioridade - os homens estão diante das coisas, situados na natureza e face a ela" (CHAUI, M. 1970, p. 134). Considerar-se fora da natureza, em face a ela, é encontrase em estado de abstração do Todo. $\mathrm{O}$ que Espinosa faz é partir de uma imagem abstrata dos homens (imagem que oferece a ilusão de um controle imperial: decidir, conduzir e regrar todas as suas coisas); entretanto, se assim fosse os homens jamais seriam vítimas da superstição, explica o nosso filósofo.

A segunda parte da hipótese continua: "ou se a fortuna se lhes mostrasse sempre favorável" (ES-
PINOSA, Op. Cit.). Oriunda do universo teológico a fortuna é "imperatrix mundi", nos escrevem os Carmina Burana. Deusa da glória e da riqueza, a fortuna representa o imprevisto, a volatilidade da vida, as circunstâncias que fogem ao nosso controle. Ora nossa sorte, ora nossa perdição, a fortuna detém a roda da vida. Como disse Boécio: "Assim ela brinca, assim ela dá prova de seu poder, e oferece aos seus súditos um grande espetáculo: o de um homem que em uma hora passa da desgraça à glória" (2012, p. 42). Experiência da contingência, a fortuna também é a experiência da insegurança e, por isso, do medo. Nenhuma alma poderia descrever melhor essa experiência do que a do melancólico, afinal, como escreve Espinosa, "a sua senhora é a Fortuna". Robert Burton, melancólico confesso, descreveu-se nas primeiras páginas de sua Anatomia da Melancolia como um observador das fortunas do mundo:

[Sou] um mero espectador das fortunas e venturas alheias, de como atuam em seus papéis, que, penso, sãome tão diversamente apresentados, como se num teatro ou cena pública. [...]

\footnotetext{
${ }^{29}$ Em latim casa se chama domus e o poder sobre ela dominium. O regente que possui o dominium absoluto sobre o patrimonium é o Pater. A instância do pater não é a de um progenitor natural (genitor), é maior do que isso, trata-se do poder judicial e senhoril. É neste sentido preciso que a igreja dizia "Deus é Pai”. Cf: CHAUI, Marilena. Mito Fundador e Sociedade Autoritária in Escritos de Marilena Chaui Vl. II - Manifestações ideológicas do autoritarismo brasileiro. Org. André Rocha. Autêntica Editora, São Paulo, 2013; p. 156.
} 
Um é liberto, o outro aprisionado; um enriquece, o outro quebra; este prospera, e seu vizinho está falindo; ora fartura, ora carestia e fome; um corre, outro cavalga, combate, ri, chora, etc. Isso eu ouço a cada dia, e outro tanto de notícias públicas e privadas, entre a galanteia e a miséria do mundo, jovialidade, orgulho, perplexidades e preocupações, simplicidade e vilania; sutileza, patifaria, candor e integridade, mutuamente misturado e ofertado" (BURTON, R. 2013 [I], p. 58).

No palco da vida e no coro do mundo, quem abre e fecha os atos é a Fortuna. No espetáculo em que a Fortuna é roteirista, a protagonista é a melancolia. Um ponto importante é que a fortuna acentua ainda mais a exterioridade, como manifesta as palavras de Burton: "[sou] um mero espectador". Sob essa perspectiva o mundo se abre como espaço no qual as coisas se relacionam entre si contingentemente em uma "incerta fortuna" . Expectador, o homem não possui a capacidade deliberativa, não é regente, restando-lhe apenas esperar pela "bona fortunae". Aqui também a conclusão é negativa: "Si fortuna ipsis prospera semper foret". Se a fortuna se mostrasse sempre próspera, se na 'cena pública' as coisas sempre fossem boas, se no palco do mundo só se apresentasse o bonum, então os homens não seriam vítimas da superstição.

A abertura do TTP aponta as condições necessárias para que os homens jamais sejam vítimas da superstição: (I) a presença de um certo consilio sobre "omnes res" ou (II) uma fortuna "semper prospera". Ora, uma vez que a fortuna é aquilo que escapa ao nosso poder, podemos supor que o problema da superstição possa ser resolvido pela via da deliberação certa (o certo consilio), ou seja, pela contínua ampliação de nossa capacidade deliberativa. Isso parece assegurado pela presença do vocábulo vel [ou] indicando que basta a presença de apenas uma das condições - (I) ou (II) para que a superstição deixe de imperar sobre os homens. Entretanto, vale notar que todas as expressões são totais: nenhuma superstição, deliberação certa sobre todas as coisas, uma fortuna sempre próspera. Embora seja totalmente aceitável do ponto de vista de outros trechos da obra de Espinosa deduzir que quanto mais capenga for a nossa capacidade deliberativa mais atuará sobre nós o imperioso poder da fortuna e, consequentemente, da superstição, não nos parece que na abertura do TTP haja condições para a dedução de uma solução. Esperar que os homens sempre deliberem de maneira certa ou que o mundo não lhes apareça fortuito é o mesmo que desejar que a vela queime sem se queimar. As únicas duas maneiras de con- 
ceber os homens como estando absolutamente fora das garras da superstição são: (I) concebendo mentalmente outros homens, isto é, substituindo a natureza humana por outra abstrata; ou (II) concebendo os homens num espaço imaginário, no qual eles se encontram abstraídos de toda experiência da contigência. Embora conceber essas condições não nos seja impossível mediante um experimento mental (uma hipótese) é certo que, in rerum natura, elas versam sobre impossibilidades. Apesar de 'nada ser fingido', claramente 'intelige-se que é impossível'. Em última instância as duas condições redundam em que a humanidade deixe de ser humanidade e que o mundo deixe de ser mundo. Confundir a hipótese inicial do TTP uma espécie de experimento mental - com a fala sobre possibilidades extramentais reais é entrar no campo da abstração. Na verdade, o sentido mais profundo da hipótese na abertura do TTP consiste em mostrar que a própria noção de "nulla superstitione" é uma abstração

A lição oferecida por Espinosa na abertura do TTP é a que a supersti- ção é intrínseca à condição humana, faz parte do que significa ser humano e viver neste mundo. Se é preciso fazer uma crítica à superstição é preciso primeiro reconhecê-la e trabalhá-la. Isto é, é preciso positivá-la enquanto objeto da reflexão, tomá-la a partir de suas causas e observar o desenvolvimento de sua trama. Em suma, é preciso abandonar a concepção abstrata - postura do sentinela que vigia à distância, nas fortalezas de sua torre - e entrar na concretude do Real. Em outros termos: é preciso deixar de tomar a superstição como coisa exterior e alheia, pertencente aos outros (de sorte, hereges ou ignorantes). A postura de sentinela da superstição redunda numa ação que impõe uma relação autoritária entre aqueles que dizem-se não-supersticiosos e os tidos por supersticiosos. $\mathrm{Na}$ tradição cristã isso se deu pelos senhores da moral e oficiantes do culto; na tradição científica assumiram este papel os portadores das luzes na sua marcha pelo aufklärung. Ora, se tivermos em mente que para Espinosa a abstração é considerar a parte fora do Todo, entenderemos que a ideia de um ho-

\footnotetext{
${ }^{30}$ Se levarmos em conta o que Espinosa fala sobre o cavalo e o inseto na Ética visualizaremos o que a hipótese de abertura do TTP aponta: todo projeto de erradicação absoluta da superstição é um projeto genocida. "O fato é que um cavalo, por exemplo, é destruído [destruitur] tanto ao ser mudado em homem como em inseto" (E, IV, praef.). Não há evolução do cavalo para o homem, assim como também não a há declínio do cavalo para o inseto, tanto num caso como no outro há apenas destruição. Querer que cavalos atuem como homens é, em última instância, desejar a destruição dos cavalos. Essa metáfora ganha força quando vinculada à hipótese inicial do TTP, afinal, desejar que as pessoas estejam absolutamente livres da superstição é o mesmo que desejar que elas deixem de ser humanas. Desejo esse que não passa de uma das faces do desejo de destruição dos homens e do mundo. Trata-se de um desejo suicida — quando referido à subjetividade — e de um desejo genocida — quando referido ao mundo e à intersubjetividade. A abertura do TTP indica que pela primeira vez na história da filosofia a superstição não será tratada como algo a ser erradicado e eliminado, uma espécie de posição higienizadora, mas como algo intrínseco aos homens e com o qual devemos aprender a lidar.
} 
mem regente consiste em pura abstração autorreferente, pois nela nós não estamos mudando ou abstraindo características de um objeto; antes nós mesmos nos tomamos numa perspectiva abstrata, separados do mundo e regentes dele - versão extrema da abstração de si. Não é apenas um perder-se de si, é a reificação em si mesmo de uma imagem abstrata de si.

$\mathrm{O}$ engenho de Espinosa não para nisso, antes o filósofo aponta que tal abstração se inscreve na própria imagem fundante da sociedade ocidental. O leitor não demorará a perceber isso se fizermos a seguinte pergunta: dentro da mitologia judaico-cristã qual é o momento em que o homem possui plena regência sobre o mundo, gozando de perfeição, e vive num paradisíaco mundo afortunado? A hipótese de abertura do TTP aponta para o Jardim do Éden: paraíso onde nosso pai terrestre, Adão, antes da queda, gozava de perfeição (poder regencial sobre si e domínio sobre todas as coisas) e vivia em um mundo em que a fortuna sempre se lhe mostrava benéfica. O engenho da hipótese inicial do TTP está no fato de Espinosa afirmar que se em algum momento o homem gozasse de tais condições ou de tal natureza ele jamais seria vítima da superstição 21 . Eis a retórica da hipótese inaugural do TTP: propor um expe- rimento mental que à primeira vista pode ser tomado como abstrato, mas que ao fim e ao cabo implode a própria concepção abstrata que os homens possuem de si. Retórica contra os retóricos, o ato inaugural do TTP subverte o mito adâmico, nos arrebata da abstração lançando-nos na trama do Real. A abertura do TTP é uma guerra contra a imagem abstrata do homem e contra as propostas genocidas que decorrem dessa abstração. Falamos em guerra porque ela opera de maneira retórica, partindo do que é comum - a concepção teológica do homem - para em seguida subvertê-la. A instância dessa guerra é a mente dos leitores 'que poderia filosofar mais livremente caso não julgassem que a razão deva ser serva da teologia' (ESPINOSA, 2003, p. 14).

A hipótese-retórica do início do TTP é um convite a pensar a condição humana sem as abstrações e os fantasmas que a tradição teológica cunhou. Afastado o paraíso - agora perdendo-o de nossas vistas para sempre - qual é a condição humana? A resposta vem logo em sequência: reduzidos, amantes e desejosos, experimentando a perda constante dos objetos amados e o escape dos desejados, os homens se encontram arrastados de um lado ao outro num turbilhão de afetos que por fim os leva à supers-

\footnotetext{
31 A formulação mais evidente da questão posta na hipótese inaugural do TTP se encontra no capítulo II $\S 6$ do Tratado Político, onde Espinosa questiona sobre "como pode acontecer, além disso, que o primeiro homem, estando de posse de si próprio e sendo e senhor de sua vontade, se deixasse seduzir e enganar?" (ESPINOSA, 2014 [I], p. 376).
} 
tição (ESPINOSA. 2003, p. 5) - eis a realidade desesperadora a qual Espinosa nos apresenta em todas as suas tramas. Mas, se o nosso filósofo faz isso é porque sabe que a única possibilidade de fazer uma política verdadeira é quando partimos da realidade concreta e não das abstrações. Uma verdadeira política dos homens, não uma utopia ou uma sátira, exige como seu princípio a veemente recusa da abstração de si.

\section{$* * *$}

Neste ponto, ao final do artigo, podemos afirmar que a abstração é não meramente uma operação mental, mas também uma abstração de si. Justamente porque nos encontramos arre- batados de nós mesmos é que produzimos abstrações. Neste sentido é interessante lembramos as palavras de Espinosa no Breve Tratado a respeito do conhecimento claro: "denominamos conhecimento claro àquele que não é por convencimento da razão, mas sim por um sentir e gozar a própria coisa" (KV, II, cap. 2 §2) e, caso algum homem chegue a contemplar algo por essa maneira de conhecer, "dirá em verdade que a coisa é assim, considerando que ela está nele, e não fora dele" (idem, cap. 4 §2). É que a verdade, ao contrário da abstração, envolve uma interioridade, um encontro consigo mesmo que é outro nome da liberdade.

\section{Referências}

AGOSTINHO, S. Verdadeira Religião trad. Nair de Assis Oliveira. $2^{\mathrm{a}}$ Ed. São Paulo: Editora Edições Paulinas, 1987.

AKKERMAN, Fokke. Le caractère rhétorique du Traité théologico-politique, in Spinoza, entre lumières et romantisme. Les cahiers de Fontenay, $n^{\circ} 36$ a 38, mars 1985 , p. 381-98.

ARNAULD, A. \& NICOLE, P. Lógica ou a arte de pensar. Trad. Nuno Fonseca. 1 edição, Lisboa: Fundação Calouste Guilbenkian; 2016.

BACON, F. Novum Organum ou Verdadeiras Indicações Acerca da Interpretação da Natureza in Coleção Os Pensadores. Trad. e Notas de José Aluysio Reis de Andrade. São Paulo: Editora Nova Cultural, 1999.

BOÉCIO. Consolação da Filosofia. Trad. Willian Li. $2^{\circ}$ Edição. São Paulo: Martins Fontes, 2012.

BURTON, R. Anatomia da Melancolia Vl I. Tradução de Guilherme Gontijo Flores. Curitiba: Editora UFPR, 2013.

CÉSAR, J. V. Abstrato ou concreto? Revista Letras; vl 9, 1958; p. 24-34. 
CHAUI, M. A Nervura do Real - Tomo I. São Paulo: Companhia das Letras, 1999.

Introdução à leitura de Espinosa. Tese de Doutoramento apresentada à Faculdade de Filosofia, Letras e Ciências Humanas da Universidade de São Paulo. São Paulo, 1970.

Da Realidade Sem Mistérios ao Mistério do Mundo (Espinosa, Voltaire, Merleau-Ponty). Ed. Brasiliense, Madrid e São Paulo 1981.

ESPINOSA. Ética. Tradução do Grupo de Estudos Espinosanos. Coordenação Marilena Chaui. São Paulo: Editora Edusp, $1^{\mathrm{a}}$ Ed, 2015.

Breve Tratado de Deus, do Homem e do seu Bem-estar. Pref. Marilena Chaui. Intr. Emanuel Angelo da Rocha Fragoso, Erika Itokazu. Trad. e notas Emanuel Angelo da Rocha Fragoso e Luis César Guimarães Oliva. Belo Horizonte: Autêntica Editora 2012.

Princípios da Filosofia Cartesiana e Pensamentos Metafísicos. Trad. Homero Santiago e Luis César Guimarães Oliva. Belo Horizonte /São Paulo: Autêntica Editora, 2015.

Tratado Teológico-Político. Trad. introd. e notas de Diogo Pires Aurélio. São Paulo: Martins Fontes, 2003.

Correspondencia. Trad. Introd. notas e In. de Atilano Domínguez. Madrid: Alianza Editorial, 1998.

Tratado da Emenda do Intelecto. Trad. Cristiano Novaes de Rezende. Campinas: Editora da Unicamp, 2015.

Spinoza Obra Completa Vl II: Correspondência Completa e Vida. Org. J. Guinsburg, Newton Cunha e Roberto Romano. Trad. e Notas J. Guinsburg e Newton Cunha. São Paulo: Editora Perspectiva, 2014.

NEWLANDS, S. Reconceiving Spinoza. $1^{\text {a }}$ Edição. New York: Oxford University Press; 2018.

"Spinoza's Early Anti-Abstractionism" In: MELAMED. Y. Y. The Young Spinoza: a metaphysician in the making. $1^{\circ}$ edição. New York: Oxford University Press; 2015. p. 255-71.

SANTIAGO, Homero. Geometria do Instituído - Estudo sobre gramática hebraica espinosana. Fortaleza: Editora UECE., 2014.

LÍVIO, Teixeira. A Doutrina dos Modos de Percepção e o Conceito de Abstração na Filosofia de Espinosa. Editora UNESP. São Paulo, 2001.

REZENDE, C. N. "O Estatuto das Hipóteses Científicas na Epistemologia de Espinosa". Cadernos de História de Filosofia e Ciência, Campinas, Série 3, v. 18, n. 1, jan.-jun. 2008. p. 147-71.

Os Perigos da Razão Segundo Espinosa: A inadequação do terceiro modo de perceber no Tratado da Emenda do Intelecto. Cadernos de His- 
tória de Filosofia e Ciência, Campinas, Série 3, v. 14, n. 1, jan.-jun. 2004. p. 59-118.

A gênese textual da doutrina da educação das crianças no Tratado da Emenda do Intelecto de Espinosa. Filosofia e Educação, volume 5, $\mathrm{N}^{\mathrm{o}}$ 1, abril - setembro de 2013. p. 52-110.

ZATERKA, L. A Filosofia Experimental na Inglaterra do Séc. XVII: Francis Bacon e Robert Boyle. São Paulo: Humanitas, 2004.

Recebido: 02/07/2019

Aprovado: 08/09/2019

Publicado: 17/11/2019 
